\title{
Pola Spasial Permukiman Tradisional Bali Aga di Desa Sekardadi, Kintamani
}

\author{
Ni Ketut Agusintadewi \\ Jurusan Arsitektur, Fakultas Teknik, Universitas Udayana \\ nkadewi@unud.ac.id
}

\begin{abstract}
ABSTRAK
Desa Sekardadi merupakan salah satu turunan Desa Bayung Gede yang memiliki kekerabatan sangat kuat. Namun, tidak seperti desa induk, Desa Sekardadi belum terdokumentasi secara baik sebagai desa tua di Kabupaten Bangli karena masih sangat jarang digunakan sebagai objek penelitian. Desa Sekardadi memiliki keunikan pada pembentukan pola spasial permukiman dan tata letak huniannya. Keunikan pola spasial permukimannya menarik untuk diungkap lebih jauh, baik filosofi maupun perwujudannya secara fisik. Dengan pendekatan deskriptif eksploratif secara kualitatif, penelitian ini bertujuan untuk menemukenali dan memaparkan karakteristik Desa Sekardadi, fisik maupun nirfisik. Variabel penelitian ditentukan berdasarkan teori housing pattern dari Habraken (1978) dan Turgut (2001), sehingga didapatkan tiga variabel setting: 1) Budaya; 2) Perilaku; dan 3) Spasial. Hasil penelitian menunjukkan bahwa pola ruang makro Desa Sekardadi dibagi menjadi tiga zona: 1) Utama Mandala terletak pada sisi utara desa; 2) Madya Mandala berada di tengah-tengah desa, dan 3) Nista Mandala pada sisi selatan desa. Pola spasial mengikuti konsep hulu-teben (tinggi-rendah) atau pola linier dengan jalan utama desa sebagai sumbu utama. Dataran lebih tinggi bernilai sakral (parahyangan) yang ditandai dengan Pura Puseh dan dataran rendah memiliki nilai profan (palemahan) dengan keberadaan kuburan, sedangkan di tengah adalah permukiman penduduk sebagai area pawongan.
\end{abstract}

Kata kunci: pola spasial; permukiman tradisional; Desa Sekardadi

\begin{abstract}
The Bayung Gede village has derived smaller traditional settlements around Kintamani. Sekardadi is one of these settlements that has an inherent consociates with the village of origin, or the Bayung Gede. Despite the fact that the Sekardadi has a uniqueness on spatial pattern and house lay out, this village has not been welldocumented as an old village in Bali. These uniqueness are interesting to be indepth explored. It is not only on the basic philosophy of the house pattern, but also how this pattern to be physical implemented. This study aims to describe some characteristics of the village, both physical and nonphysical aspects, through the way of descriptive exploratory qualitative approach. According to the theory housing pattern of Habraken (1978) and Turgut (2001), research variables are determined into three variables: 1) Cultural setting; 2) Behavioural setting; and 3) Spatial setting. The result shows that macro spatial pattern of the Sekardadi village is divided into three zones: 1) Utama Mandala locates in the north of the village; 2) Madya Mandala is in the middle of the village, and 3) Nista Mandala in the south. Spatial pattern follows the hulu-teben conception or linear pattern with the main road as a cardinal orientation. Higher land means a sacred area (parahyangan) that is characterized by the existence of Pura Puseh. Meanwhile, the opposite is defined as a profane area (palemahan) with the presence of graves; and in the middle is the settlement (pawongan).
\end{abstract}

Keywords: spatial pattern; traditional settlement; Sekardadi village 


\section{Pendahuluan}

Bali memiliki tatanan dalam berbagai aspek kehidupan, termasuk dalam hal permukiman. Tidak hanya bentuk bangunannnya saja yang khas, tetapi demikian pula halnya dengan pola desanya. Desa Sekardadi adalah salah satu Desa Bali Aga (pegunungan) yang ada di Bali. Desa ini memiliki pola ruang makro yang khas seperti desa-desa yang ada di Bali. Peruntukan lahan di Desa Sekardadi sebagian besar digunakan sebagai lahan perkebunan, yang merupakan perkebunan rakyat dengan hasil utama cengkeh dan kopi. Pola permukiman makro Desa Sekardadi dilandasi oleh konsep Tri Hita Karana dan Tri Mandala, tata ruang makro dibagi menjadi tiga zona. Zona Mandala Utama terletak pada sisi utara Desa yang dibatasi oleh batas Banjar Dauh Pura, Zona Madya Mandala berada di tengah-tengah Desa dengan batas sisi utara dan selatan merupakan batas Banjar Dauh Pura. Sedangkan yang terakhir adalah Zona Nista Mandala yang berada pada sisi selatan Desa Sekardadi.

Berdasarkan data sejarah, bersama-sama beberapa desa lainnya, Desa Sekardadi merupakan salah satu turunan dari Desa Bayung Gede yang memiliki kekhasan pada pola permukiman dan tata huniannya. Desa Bayung Gede merupakan desa bersejarah yang telah berkembang menjadi banyak desa lain dengan tetap mempertahankan sebagian besar budaya bermukimnya. Namun, dalam kurun waktu delapan dekade (sejak 1930an, dimana untuk pertama kalinya desa ini berhasil diidentifikasi oleh Margaret Mead, dkk), terakhir mengalami perubahan bentuk fisik utamanya yang berkenaan dengan unit hunian. Fenomena perubahan yang dilakukan oleh penghuni telah terbukti secara ilmiah didorong oleh adanya perubahan gaya hidup dan cara pandang penghuni terhadap huniannya serta perubahan demografi (Manik, 2007:V).

Sebagaimana Desa Bayung Gede pada masa identifikasi Mead (tahun 1936), tata letak hunian Desa Sekardadi juga mengikuti pola seperti pada desa induknya yaitu tiga massa bangunan di dalam satu unit hunian (kavling). Ketiga massa bangunan tersebut secara serentak berulang kembali di setiap unit hunian, yaitu(secara berurutan dari pintu masuk utama pekarangan): (1) Jineng/lumbung, tempat menyimpan hasil pertanian/perkebunan; (2) Bale Pegaman, tempat tidur anak-anak dan menyimpan perlengkapan upacara; (3) Paon/Dapur, yang berfungsi untuk menyiapkan logistik keluarga sekaligus ruang tidur orang tua. Beberapa aspek fisik unit lingkungan juga memiliki kekhasan dan keseragaman yang menunjukkan dimasa lalu, pihak otoritas desa telah menyiapkan semacam regulasi tradisional yang mengatur keteraturan di dalam desa ini. Di masa kini, banyak dari sekian kesepakatan untuk teratur itu dapat kita temui bentukannya di lingkungan desa.

Keunikan pada pola spasial permukiman tradisional ini menjadi menarik untuk diungkap lebih jauh lagi. Bagaimana masyarakat Bali Aga di pegunungan membentuk pola permukiman di Desa Sekardadi? Bagaimana perwujudan konsep Tri Hita Karana dan Tri Mandala dalam pembentukan pola permukiman tersebut? Pertanyaanpertanyaan tersebut menjadi bahan ulasan dalam tulisan ini. Sebagaimana para antropolog menyebutkan Desa Sekardadi sebagai Bali Muna atau Bali Kuna yang bermakna orang Bali asli atau kuno karena masih mempertahankan tradisi budaya sebelum munculnya kebudayaan Bali, maka desa ini menjadi menarik dan penting untuk dieksplorasi lebih jauh.

Selain itu, tidak seperti Desa Bayung Gede dan Desa Penglipuran yang telah sering diteliti oleh banyak ahli dari berbagai disiplin ilmu, penelitian tentang Desa Sekardadi masih sangat terbatas. Sejumlah penelitian pendahulu telah dilakukan, namun masih dalam perspektif antropologi dan arkeologi. Sampai saat ini belum ditemukan penelitian dari perspektif arsitektur, sehingga Desa Sekardadi dapat 
dikategorikan sebagai desa tua di Kabupaten Bangli yang belum terdokumentasi dengan baik.

Untuk menjawab pertanyaan-pertanyaan di atas, untuk menemukenali dan menjelaskan perwujudan nilai-nilai filosofi pada pola spasial permukiman Desa Sekardadi, maka analisis yang digunakan bersifat deskriptif eksploratif secara kualitatif. Variabel penelitian ditentukan berdasarkan teori housing pattern dari Habraken (1978) dan Turgut (2001), sehingga didapatkan tiga variabel setting: 1) Budaya; 2) Perilaku; dan 3) Spasial. Pandangan masyarakat Bali Aga terhadap hunian dan permukimannya dipelajari melalui studi pustaka sebagai sumber sekunder dikaitkan dengan wawancara dengan para pemuka adat dan warga masyarakat dan nara sumber lainnya.

Penelitian ini merupakan penelitian awal yang dilakukan oleh Penulis dalam menjelajahi arsitektur tradisional Bali Aga di wilayah Kabupaten Bangli. Dengan adanya penelitian ini, generasi mendatang diharapkan tetap dapat memiliki kesempatan untuk mengetahui arsitektur rumah tradisional dan permukiman Bali Aga di Desa Sekardadi. Selain itu, hasil penelitian ini dapat menjadi dokumentasi yang inklusif secara lengkap dan menyeluruh, sehingga memudahkan bagi peneliti-peneliti selanjutnya untuk mengungkap lebih banyak lagi 'rahasia-rahasia' yang tersimpan dari kekhasan desa ini.

\section{Bahan dan Metode}

Penelitian ini bersifat deskriptif eksploratif secara kualitatif yang memaparkan data lapangan secara menyeluruh atas kelompok data yang bersesuaian. Penelusuran pustaka akan memperkuat hasil wawancara maupun observasi lapangan. Penelitian bertujuan untuk mengidentifikasi kondisi terkini lingkungan desa (berikut unit huniannya), serta sistem kepercayaan dan sosial kemasyarakatannya.

Tabel 1. Variabel penelitian

\begin{tabular}{|c|c|}
\hline $\begin{array}{l}\text { Faktor Pembentukan Pola Permukiman } \\
\text { (housing pattern) }\end{array}$ & Variabel Penelitian \\
\hline Habraken (1978) & \multirow{10}{*}{$\begin{array}{l}\text { 1. Setting budaya (sistem } \\
\text { kepercayaan, sistem sosial } \\
\text { kemasyarakatan, dll.) } \\
\text { 2. Setting perilaku } \\
\text { (tradisi/kebiasaan, hubungan } \\
\text { sosial dan kekerabatan dalam } \\
\text { keluarga, dll.) } \\
\text { 3. Setting spasial (pola spasial } \\
\text { permukiman) }\end{array}$} \\
\hline $\begin{array}{l}\text { Sistem Spasial (organisasi ruang yang termasuk hubungan antar ruang, } \\
\text { orientasi, pola hubungan antar ruang, dll.) }\end{array}$ & \\
\hline - Sistem Fisik (penggunaan sistem konstruksi serta bahan bangunan) & \\
\hline $\begin{array}{l}\text { Sistem Style (bentuk, fasade, bentuk pintu, bentuk jendela, serta unsur- } \\
\text { unsur ragam hias di dalam (interior) atau di luar bangunan (eksterior) }\end{array}$ & \\
\hline Turgut (2001) & \\
\hline $\begin{array}{l}\text { Setting Spasial (organisasi ruang yang termasuk hubungan antar ruang, } \\
\text { orientasi, pola hubungan antar ruang, bentuk, fasade, bentuk pintu, } \\
\text { bentuk jendela, serta unsur-unsur ragam hias di dalam (interior) atau di }\end{array}$ & \\
\hline $\begin{array}{l}\text { luar bangunan (eksterior), penggunaan sistem konstruksi serta bahan } \\
\text { bangunan, dll.) }\end{array}$ & \\
\hline $\begin{array}{l}\text { Setting Perilaku (tradisi/kebiasaan, hubungan sosial dan kekerabatan } \\
\text { dalam keluarga, dll.) }\end{array}$ & \\
\hline - Setting Budaya (sistem kepercayaan, sistem sosial kemasyarakatan, dll.) & \\
\hline $\begin{array}{l}\text { - Setting Sosial Ekonomi (mata pencaharian,sumber pendapatan desa, } \\
\text { tingkat penghasilan, dll.) }\end{array}$ & \\
\hline
\end{tabular}

Sumber: dikembangkan dari Habraken (1978) dan Turgut (2001)

Pengumpulan data dilakukan dengan menggabungkan pendapat Habraken (1978) dan Turgut (2001) mengenai budaya permukiman, sehingga dapat ditentukan variabel-variabel penelitian yang menjadi panduan dalam penelusuran data selama di lapangan, lihat Tabel 1 . Kedua teori ini merupakan penjelasan lebih lanjut dari teori 
Rapoport (1977) mengenai setting sebagai unsur utama pembentuk lingkungan. Setting ini memperlihatkan pola kegiatan serta proses mewujudkan wadah aktifitas, baik secara fisik maupun nirfisik (Rapoport, 1977). Tabel berikut merupakan modifikasi dari kedua teori tersebut sebagai variabel pendukung pembentukan pola permukiman (housing pattern). Variabel-variabel yang akan digunakan untuk melakukan identifikasi adalah: (1) Setting spasial; (2) Setting perilaku; (3) Setting budaya; yang kesemuanya membentuk housing pattern atau pola perumahan suatu permukiman. Variabel (1) merupakan aspek fisik permukiman, sedangkan Variabel (2) dan (3) merupakan aspek nirfisik desa.

\section{Hasil dan Diskusi}

\subsection{Sejarah Desa}

Studi-studi antropologi terdahulu (Bateson, 1970; Geertz, 1959; Mead dkk, 1942) menunjukkan bahwa Bali dan budayanya telah menjadi bahan permenungan bagi penelitian etnografi dunia. Sebagaimana diungkap secara lugas oleh Reuter (2005:9-10) wilayah-wilayah ritual di daratan tinggi Bali itu dipersatukan oleh orientasi bersama dari asal-usul yang sama. Pengistilahan secara topografis penduduk Pegunungan Bali mengacu pada jarak fisik yang memisahkan penduduk dataran tinggi dengan penduduk di sekitar pusat-pusat politik dan perkotaan yang terletak di wilayah Bali Selatan. Istilah Bali Aga didefinisikan secara harfiah sebagai bangsa yang jauh dan terpinggirkan. Sebagian para ahli menyebutknya sebagai Bali Muna atau Bali Kuna yang bermakna orang Bali asli atau kuno. Dengan demikian pemaknaan istilah Bali Aga kemudian direpresentasikan sebagai penduduk asli yang masih mempertahankan suatu tradisi budaya yang berasal dari sebelum munculnya kebudayaan Bali sebagaimana didefinisikan oleh orang Bali Selatan (Reuter, 2005). Kemudian Reuter juga menegaskan bahwa terminologi Bali Aga dipertahankan karena pegunungan merupakan tempat tinggal para dewa-dewi yang suci dalam kosmologi orang Bali, selain juga sebagai sumber air.

Sejarah Desa Sekardadi tidak bisa dipisahkan dengan sejarah Desa Bayung Gede sebagai desa induk dan 28 desa turunan lainnya, termasuk Desa Sekardadi. Dari tiga di antaranya memiliki pertalian darah penghuni yang cukup erat. Tiga desa tersebut terletak di Kabupaten Bangli, antara lain Desa Sekardadi, Penglipuran, dan Tiga Kawan. Sejarah perkembangan 28 desa tersebut, khususnya yang terletak di Kecamatan Kintamani, memiliki kegiatan-kegiatan adat yang hampir serupa dengan yang dimiliki Desa Bayung Gede. Dalam beberapa kegiatan adatnya, Desa Bayung Gede mengundang perwakilan dari ke-28 desa tersebut, demikian pula sebaliknya. Biasanya dalam kegiatan-kegiatan tersebut mereka menampilkan atraksi kesenian/tari-tarian khas desanya.

\subsection{Sistem Pemerintahan}

Secara umum, sistem pemerintahan desa yang dikenal oleh masyarakat Bali adalah sistem pemerintahan desa dinas dan sistem pemerintahan desa adat. Keduanya memiliki perbedaan secara substansial, struktur dan fungsi. Keterikatan masyarakat maupun respon yang diberikan pada dua lembaga pemerintahan tersebut berbeda pula. Sistem pemerintahan adat di pimpin oleh ulu apad yaitu sesepuh desa yang terdiri dari delapan orang yaitu, 1 pasang kebaan, 1 pasang pasek, 1 pasang takin dan 1 pasang pamurakan.

Secara turun-temurun kehidupan masyarakat Desa Sekardadi tidak pernah terlepas dari adat. Begitu juga sistem organisasi sosial yang ada selalu mengacu pada 
sistem adat dan awig-awig. Hal ini lah yang mendasari sistem organisasi sosial yang kuat dan bertahan hingga kini. Jenis-jenis lembaga tradisional dalam masyarakat Bali adalah desa, banjar, subak, dan sekehe. Konsep desa memiliki dua pengertian, yaitu desa adat dan desa dinas.

\subsection{Sistem Kemasyarakatan}

Sebagai desa yang masih tradisional dan selalu menjunjung tinggi awig-awig desa, kehidupan masyarakat Desa Sekardadi selalu mengedepankan prinsip persatuan, kesatuan dan kebersamaan. Hal ini dikarenakan setiap warga memiliki tanggung jawab untuk menjaga kelestarian dan kesucian desa. Sebagai salah satu dari desa Bali Aga, desa ini memiliki budaya, dialek bahasa, dan ritual yang berbeda dari desa-desa lain di Bali. Dalam sistem sosialnya, desa ini menganut sistem ulunan atau prajuru. Sistem ulunan berarti mengedepankan kedudukan dalam keluarga berdasarkan perkawinan. Begitu seseorang menikah, maka namanya dimasukkan dalam karma adat. Selain krama desa adat tersebut terdapat pula warda desa yang disebut dengan istilah pancer (panca datu), yaitu: 1) Warga pasek bertugas untuk tetap melestarikan adat; 2) Juru gemblung yang bertugas untuk memegang gamelan sakral ketika ada upacara di pura; 3) Juru gambuh bertugas sebagai penari tari-tarian sakral; 4) Juru lawan bertugas sebagai penari saat upacara Galungan dan Kuningan; dan 5) Juru Sudamala bertugas untuk melaksanakan upacara pembersihan pada saat terjadi kematian atau upacara ngaben.

\subsection{Sistem Kekerabatan}

Sebagai salah satu desa tua di Kabupaten Bangli, keberadaan Desa Sekardadi dapat terjaga hingga kini dikarenakan dalam setiap kehidupan masyarakat selalu berpegang pada awig-awig desa. Begitu juga halnya dengan pemanfaatan wilayah desa yang telah diatur dalam ketentuan desa adat. Jika ada masyarakat yang melanggar maka akan mendapatkan sanksi, mulai dari pamindanda (denda) hingga dikeluarkan dari keanggotaan krama desa adat. Hukum adat (awig-awig) adalah aturan yang dibuat oleh warga (krama) desa adat yang dipakai pedoman dalam pelaksanaan kegiatan sehari-hari masyarakat Desa Sekardadi, baik dalam pelaksanaan tara ruang desa maupun dalam pekarangan.

Terdapat empat bentuk persekutuan dasar yang terkait dengan secara fungsional struktural yang terdapat dalam kehidupan personal masyarakat Desa Sekardadi, yaitu keluarga inti, dadia, banjar dan pakraman desa atau warga. Keempat persekutuan tersebut sangat erat kaitanya dengan hak dan kewajiban sebagai warga desa. Semakin terbukanya desa terhadap lingkungan luar menyebabkan semakin tingginya minat terhadap pendidikan, terutama generasi mudanya. Arus globalisasi juga telah masuk ke dalam desa ini, namun demikian Desa Sekardadi masih memiliki banyak keunikan dan kearifan tradisional. Di antara keunikan unikan tersebut teletak pada bahasa keseharian antar penduduk desa, sistem kepercayaan, ritual keagamaan, sistem kemasyarakatan, dan pandangan hidup.

\subsection{Analisis Karakteristik Pola Spasial Permukiman}

Analisis karakteristik pola spasial permukiman Desa Sekardadi bertujuan untuk mengetahui penerapan filosofi dan konsepsi tata ruang masyarakat tradisional Bali Pegunungan, sehingga dapat diperoleh paparan mengenai wujud penerapan filosofi tersebut secara fisik. Pengaturan tata ruang desa didasarkan pada hukum adat (awig- 
awig), begitu juga dengan pemanfaatan wilayah desa yang telah diatur oleh ketentuan desa adat. Sanksi dikenakan kepada masyarakat yang melanggar ketentuan tersebut.

\subsubsection{Analisis Tata Ruang Desa}

Menurut konsepsi masyarakat Bali pada umumnya, tata ruang yang dimaksudkan adalah aturan penempatan ruang-ruang yang mengacu pada fungsi tertentu serta tata nilai yang diberikan terhadap fungsi tersebut dengan berlandaskan pada ajaran agama Hindu di Bali (Ganesha, dkk, 2012). Pada tataran pola desa adat, Gelebet (1982:12) menyatakan bahwa desa adat di daerah Bali pegunungan, menempatkan zona sakral dengan tata nilai utama pada arah gunung sebagai kaja dan Hulu desa serta arah laut atau lawan dari gunung sebagai kelod/Teben bernilai rendah. Dengan konsep ini, desadesa pegunungan cenderung berpola linear dengan core desa sebagai penghubung zona Hulu dan Teben Desa. Sementara itu, di desa dataran di samping berpedoman pada konsep Hulu-Teben atau berdasarkan arah gunung-laut (kaja-kelod), juga menempatkan zona Hulu pada arah matahari terbit sebagai kangin bernilai utama dan matahari tenggelam sebagai zona Tebe sebagai Kauh yang bernilai nista/rendah. Dengan kedua kiblat ini, Gelebet (1982:13) menambahkan bahwa pola desa dataran umumnya berpola perempatan agung atau nyatur desa berupa dua jalan desa utama menyilang desa TimurBarat (kangin-kauh) dan Utara-Selatan (kaja-kauh) membentuk persilangan. Titik persilangan merupakan pusat desa.

Konsep Hulu-Teben merupakan salah satu konsep pola ruang makro dalam arsitektur tradisional Bali karena memiliki latar belakang atau dilatari oleh konsep keluhuran, artinya penghormatan para leluhur dalam bentuk proses penanaman mayat, kemudian pengabenan (ritual pembakaran jenazah) dan memukur atau nyekah (ritual peningkatan status sang roh menjadi roh suci/sang pitara) dan terakhir dengan upacara ngelinggihang Dewa Hyang atau dewa pitara atau meningkatkan sang pitara menjadi leluhur dan ditempatkan di sanggah kemulan/tempat suci di karang umah/rumah tinggal (Ardana, 1982:15).

Kepercayaan pada konsep Hulu-Teben (atas-bawah) yang ditampilkan dalam wujud meletakkan arah kepala mayat ke arah bukit atau gunung, kepercayaan ini merupakan keyakinan masyarakat Bali pada masa itu bahwa roh leluhur mereka berada di tempat ketinggian atau gunung. Konsep ini masih berlaku hingga kini dalam perencanaan lingkungan perumahan/perkampungan/desa di Bali. Parwata (2015:216) menegaskan bahwa apresiasi pada para leluhur saat ini banyak ditemukan dalam bentuk Sanggah/Pemerajan atau tempat suci keluarga untuk setiap rumah tinggal, kemudian berkembang ke Pura Genealogi seperti Pura Dadia, Pura Paibon serta Merajan Alit, dan pada akhirnya menyebar ke Pura Kahyangan Tiga (tiga buah tempat suci sebagai indikator religius keberadaan sebuah desa adat di Bali).

Prinsip-prinsip dalam penghormatan terhadap para leluhur di atas menjadi pedoman desain dalam arsitektur tradisional Bali yang diwarisi hingga kini, dimulai dari arsitektur tradisional Bali pegunungan yang lebih tua berupa hulu/kaja (arah gunung/ketinggian bernilai utama)-teben/kelod (arah laut bernilai nista. Ini termasuk arsitektur Bali dataran dengan ditambahkan-nya arah hulu/kangin (arah matahari terbit bernilai utama)-Teben/kauh (arah matahari tengelam bernilai nista). 


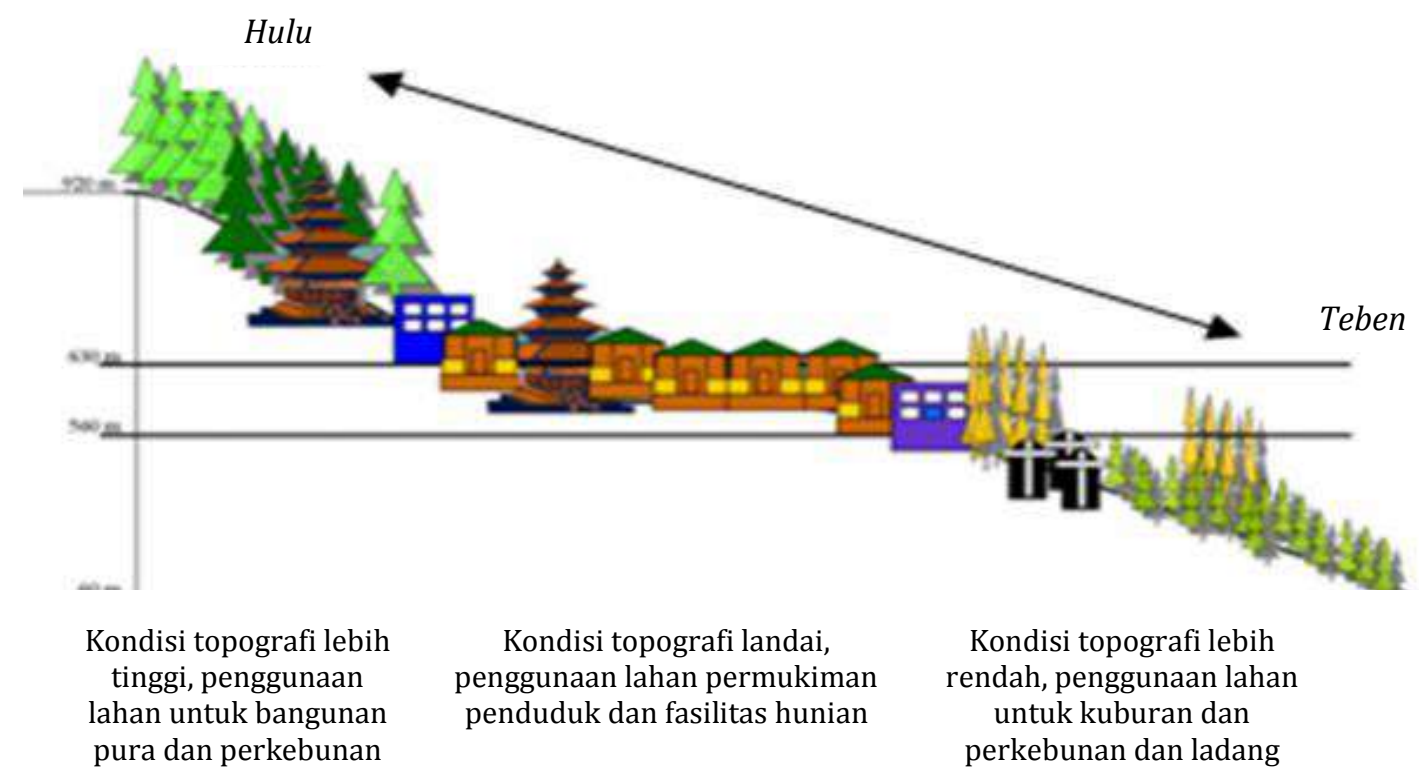

Gambar 1. Potongan melintang pola desa yang mengikuti

konsep hulu-teben (atas-bawah)

(Sumber: Ganesha, dkk, 2012:65)

\subsubsection{Tipologi Desa Adat Sekardadi}

Gelebet (1982) menyebutkan bahwa ciri utama fisik desa Bali Pegunungan adalah ruang terbuka cukup luas yang memanjang (linier) dari arah utara menuju selatan (kajakelod), yang membagi desa menjadi dua bagian. Pada posisi yang diametral, yakni pada ujung utara (kaja) terletak Pura Puseh, di tengah sebagai tempat Pura Bale Agung, dan pada arah selatan (kelod) terletak Pura Dalem. Ketiga pura tersebut dikelompokkan dalam Pura Kahyangan Tiga. Sementara itu, fasilitas umum atau infrastuktur berada di tengah desa dan hunian penduduk berada pada sisi kiri dan kanan jalan utama desa.

Pura Kahyangan Tiga merupakan indikator religius atas keberadaan sebuah desa adat di Bali, terdiri atas: (i) Pura Desa, terletak di hulu desa, didedikasikan untuk Dewa Brahma, manifestasi Tuhan sebagai Pencipta Dunia. Sementara itu, Pardiman (1986:18) menambahkan bahwa Pura Desa lebih dikenal dengan sebutan Pura Bale Agung: sebuah tempat suci dimana para warga desa melakukan pertemuan dengan para leluhurnya saat-saat upacara; (ii) Pura Puseh ditempatkan di Hulu desa/kaja, didedikasikan untuk Sri Wisnu, Tuhan sendiri sebagai Sang Pemelihara Dunia. Unsur Pura Kahyangan Tiga terakhir adalah (iii) Pura Dalem yang didedikasikan untuk Dewa Siwa, manifestasi Tuhan sebagai Pelebur Dunia). Keberadaan Pura Dalem selalu dilengkapi dengan satu kuburan (setra desa adat) di Teben desa/kelod.

Sebagai konsep tata nilai dalam pembentukan pola permukiman Bali Pegunungan yang sampai saat ini masih diaplikasikan secara turun-menurun dari generasi ke generasi, maka arah gunung merupakan hulu atau kaja sebagai zona sakral dengan hierarki tertinggi (utama). Sementara itu, arah laut merupakan teben atau kelod dengan nilai paling profan dan lebih rendah (Adiputra, 2016; Rahayu, 2012; Pardiman, 1986; Gelebet, 1982). Dengan demikian, pada zona hulu dipergunakan untuk menempatkan Pura Desa dan Pura Puseh, dua bagian dari Pura Kahyangan Tiga yang merupakan penanda religiusitas dari keberadaan sebuah desa adat (Ngoerah Gde, 1981). Pada sisi yang berlawanan, Kertiyasa (1984) menyatakan bahwa zona teben dimanfaatkan oleh desa adat sebagai tempat untuk Pura Dalem atau satu bagian dari Pura Kahyangan Tiga, dan kuburan desa adat (setra). Berdasarkan paparan tersebut, maka konsep hulu-teben merupakan pengetahuan dasar di dalam dialog pembentukan 
pola Desa Sekardadi. Dengan demikian, Gunung Batur yang terletak di kaja (utara) menjadi orientasi desa. Konsep hulu-teben membedakan ruang desa menjadi tiga zona: 1) zona hulu sebagai lokasi pura (zona parahyangan); 2) zona tengah untuk kawasan perumahan (zona pawongan); dan 3) teben merupakan zona kuburan desa adat (zona palemahan), lihat Gambar 2. Ketiga zona tersebut dilandasi oleh Konsep Tri Hita Karana (Parwata, 2004).

Permukiman tersebut dikelilingi oleh kawasan perkebunan dan tegalan dan perkembangannya yang menyebar pada lokasi pertanian yang berada pada luar desa. Kawasan perkebunan dan tegalan tersebut disebut dengan kubu yang merupakan rumah tinggal di luar pusat permukiman di ladang, di perkebunan atau tempat tempat kehidupan lainya. Lokasi $k u b u$ tersebar tanpa dipolakan sebagai suatu lingkungan permukiman, menempati unit-unit perkebunan atau ladang-ladang yang berjauhan, tanpa penyediaan sarana utilitas. Pola ruang kubu sebagai rumah tempat tinggal serupa pola dengan rumah/umah (Gelebet, dkk. 1985:39).

\subsubsection{Analisis Pengaturan Ruang Budaya Desa Sekardadi}

Pengaturan pola spasial desa yang dilandasi oleh konsep Hulu-Teben dan Tri Hita Karana, memungkinkan Desa Sekardadi memiliki pola linier (linear pattern). Jalan utama desa yang membentang dari utara ke selatan merupakan pusat yang tidak hanya berfungsi sebagai sirkulasi umum, tetapi juga berfungsi sebagai ruang terbuka yang menghubungkan pintu masuk pekarangan setiap rumah. Posisi jalan lebih rendah dari unit hunian yang mengapit jalan desa, lihat Gambar 3. Selain itu, pusat juga memiliki makna sebagai orientasi ruang publik saat melaksanakan upacara adat (Manik, 2007). Pintu-pintu pekarangan dari setiap unit hunian mengarah atau beriorientasi ke jalan utama desa. Pekarangan hanya berfungsi sebagai tempat tinggal untuk mengadakan upacara dan berhubungan dengan keluarga. Untuk memenuhi kebutuhan hidupnya, penduduk mengusahakan kebun/ladang (pategalan) di luar desa atau di luar kawasan perumahan. Keterbatasan lahan dan keinginan untuk berinteraksi dengan jalan utama menyebabkan terjadi pengembangan perumahan ke arah luanan/hulu, tetapi tetap mempertahankan untuk tidak membangun di luanan Pura.

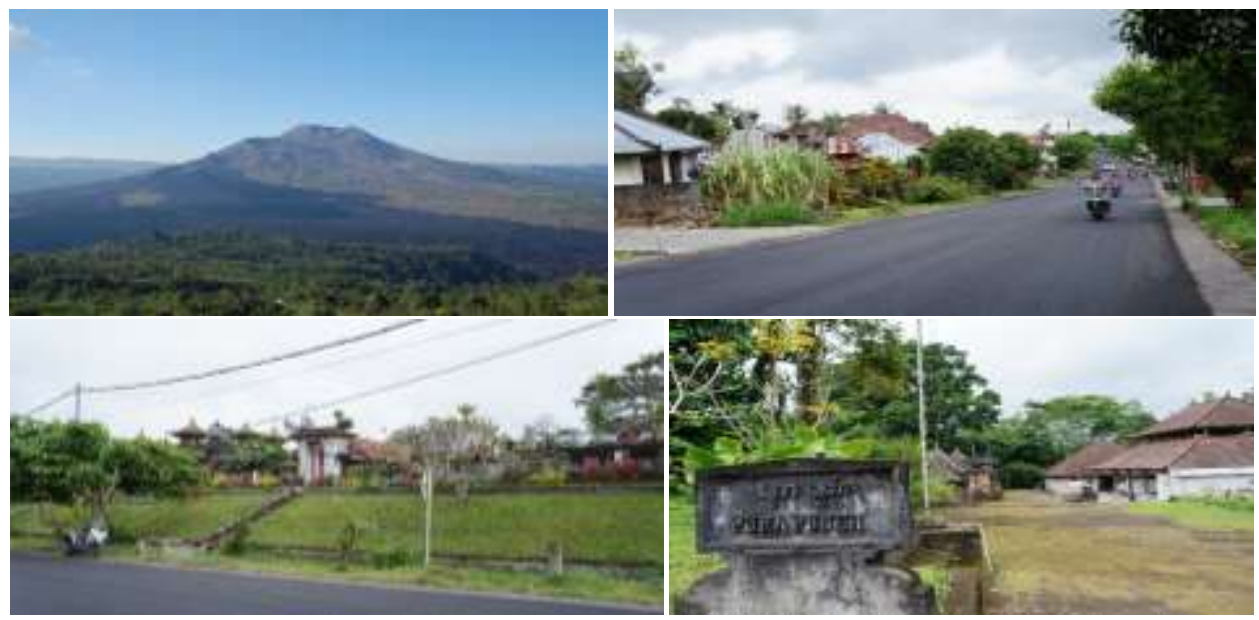

Gambar 3. Suasana permukiman Desa Sekardadi (searah jarum jam)

(1) Gunung Batur sebagai pusat orientasi desa.

(2) Jalan utama desa sebagai sumbu utama dari pola spasial pemukiman desa.

(3) Pura Puseh yang terletak pada hulu desa dengan hierarki tertinggi sebagai kawasan paling sakral (parahyangan) terletak pada Zona Utama Mandala.

(4) Deretan rumah di sepanjang jalan utama membentuk pola linier. Posisi permukiman di sepanjang jalan tersebut terletak lebih tinggi dari jalan desa.

(Sumber: Hasil observasi lapangan, September 2016, hak cipta pada penulis) 


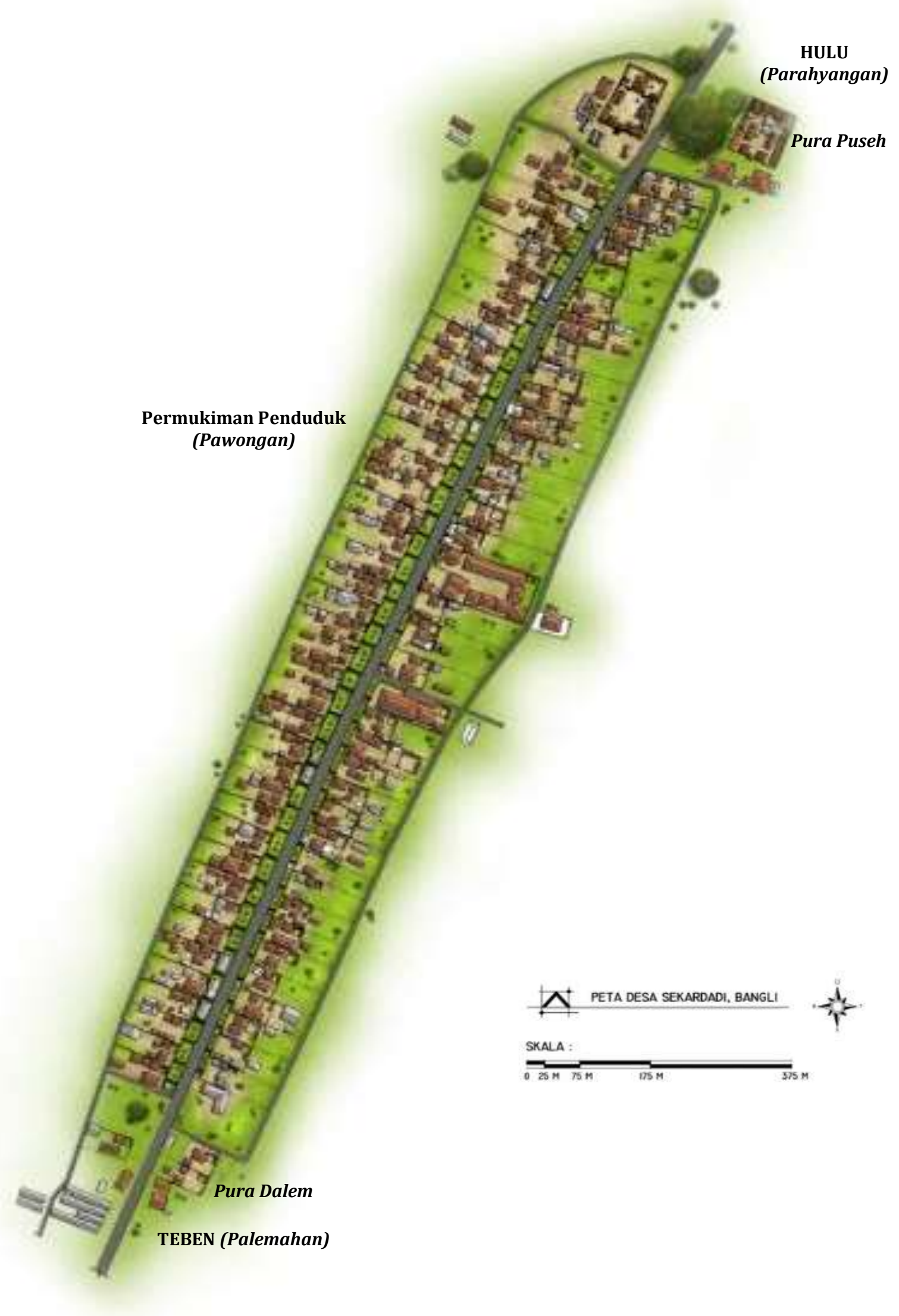

Gambar 2. Pola linier desa merupakan perwujudan dari konsep hulu-teben (Sumber: Hasil pemetaan di lapangan, September 2016, hak cipta pada penulis) 


\section{Simpulan}

Pembentukan pola spasial permukiman Desa Sekardadi mengikuti Konsepsi Tri Kita Karana (Parahyangan, palemahan, dan pawongan), Tri Mandala (Utama, Madya, dan Nista), konsepsi hulu-teben (atas-bawah) sebagai bentuk penghormatan terhadap leluhur. Gunung Batur yang terletak di sebelah utara/kaja merupakan pusat orientasi desa. Kemudian konsepsi tata nilai tersebut diterjemahkan secara fisik ke dalam pola spasial permukiman dengan jalan utama desa sebagai ruang terbuka yang memanjang (linier) dari arah utara menuju selatan (kaja-kelod), yang membagi desa menjadi tiga zona: 1) Zona hulu/kaja sebagai lokasi pura (zona parahyangan). Zona ini memiliki kondisi topografi lebih tinggi, sehingga memiliki hierarki tertinggi dan paling sakral (Zona Utama Mandala) yang ditandai dengan penempatan Pura Puseh (tempat pemujaan untuk Dewa Brahma, yaitu Dewa Penciptaan; 2) Zona tengah untuk kawasan permukiman dan fasilitas huniannya (zona pawongan) dengan kondisi topografi lebih landai sebagai Zona Madya Mandala untuk meletakkan Pura Bale Agung (tempat pemujaan untuk Dewa Wisnu sebagai Dewa Pemelihara); dan 3) Zona Teben pada ujung selatan (kelod) yang memiliki kondisi topografi lebih rendah untuk menempatkan Pura Dalem (tempat pemujaan untuk Dewa Siwa sebagai Dewa Pelebur) dan setra atau kuburan desa adat (zona palemahan). Zona ini memiliki nilai hierarki paling rendah dibandingkan dua zona lainnya (Zona Nista Mandala).

\section{Ucapan Terima Kasih}

Penulis mengucapkan terima kasih kepada Lembaga Penelitian dan Pengabdian Masyarakat Universitas Udayana (LPPM Unud) yang telah membiayai penelitian ini melalui Hibah Unggulan Program Studi (HUPS) Program Studi Arsitektur di Fakultas Teknik Universitas Udayana pada Tahun Anggaran 2016. Penulis juga mengucapkan terima kasih kepada Kepala Desa Sekardadi, Kelihan Desa Adat Sekardadi, dan beberapa warga Desa Sekardadi yang bersedia menjadi narasumber penelitian ini.

\section{Daftar Pustaka}

Adiputra, I.G.N.T. dkk. (2016). Konsep Hulu-Teben pada Permukiman Tradisional Bali Pegunungan/Bali Aga di Desa Adat Bayung Gede Kecamatan Kintamani Kabupaten Bangli, Bali, dalam Forum Teknik 37(1), Januari 2016, pp. 14-31.

Alexander, C. (1987). A New Theory of Urban Design. New York.

Ardana, I.G.N.G., dkk. (1982). Sejarah Perkembangan Hinduisme di Bali. Denpasar: Proyek Inventarisasi dan Dokumentasi Kebudayaan Bali, Departemen Pendidikan dan Kebudayaan Propinsi Dati I Bali.

Depdagri (2016). Profil Desa Sekardadi Tahun 2015. Denpasar: Dirjen Pemberdayaan Masyarakat dan Desa.

Bateson, G. (1970). 'An Old Temple and a New Myth' dalam J. Belo (Ed.) Traditional Balinese Culture. New York: Columbia University Press.

Ganesha, W.; Antariksa, Wardhani, D.K. (2012). Pola Ruang Permukiman dan Rumah Tradisional Bali Aga Banjar Dauh Pura Tigawasa dalam arsitektur e-Journal 5(2), November 2012, pp. 60-73.

Geertz, C. (1959). 'Form and Variation in Balinese Village Structure' dalam American Anthropologist 61(6), pp. 991-1012

Gelebet, I.N. dkk. (1985). Arsitektur Tradisional Daerah Bali. Departemen Pendidikan dan Kebudayaan: Proyek Inventarisasi dan Dokumentasi Kebudayaan Daerah.

Habraken, N.J. (1978). Variations: The Systematic Design of Supports. MIT Cambridge; Massachusetts. 
Kertiyasa, I.M. (1984). Rumusan Arsitektur Bali: Hasil Sabha Arsitektur Tradisional Bali. Denpasar: Pemda Tingkat I Bali.

Manik, I.W.Y. (2007). Pengaruh Demografi, Gaya Hidup, dan Aktifitas terhadap Transformasi Tipo-Morfologi Hunian Tradisional di Desa Bayung Gede, Bali. Tesis. Bandung: Program Pascasarjana Magister Arsitektur, ITBBandung.

Mead, M. dkk. (1942). Balinese Character: A Photographic Analysis. New York: Academy of Sciences.

Ngoerah, I G.N.G. 1981. Laporan Penelitian Inventarisasi Pola-Pola Dasar Arsitektur Traditional Bali. Ujung Pandang: Dirjen Pembinaan dan P3M Dirjen Dikti, Depdikbud, Lembaga Penerbitan Universitas Hasanuddin.

Pardiman, A. (1986). Fundamental Study on Spatial Formation of Island Village: Environmental Study Hierarchy of Sacred-Profane Concept in Bali, PhD Thesis. Kyoto: Kyoto University.

Parwata, I.W. 2004. Dinamika Permukiman Perdesaan Pada Masyarakat Bali. Denpasar: Direktorat Jenderal Pendidikan Tinggi

Rahayu, N.M.S. (2012). Konsep Hirarkhi Ruang pada Rumah Tinggal Tradisional di Desa Adat Sembiran, Kecamatan Banjar, Kabupaten Buleleng, Bali, Tesis. Denpasar: Program Studi Magister Arsitektur Universitas Udayana.

Rapoport, A. (1969). House Form and Culture. University of Winconsin, Milwaukee.

Rapoport, A. (1977). Human Aspects of Urban Form: Towards a Man-Environment Approach to Urban Form and Design. University of Winconsin, Milwaukee.

Rapoport, A. (1983). Development, Culture Change, and Supportive Design. University of Winconsin, Milwaukee.

Reuter, T.A. (2005). Custodians of the Sacred Mountains: Budaya dan Masyarakat di Pegunungan Bali. I Nyoman Dharma Putra (Penyunting). A. Rahman Zainuddin (Alih Bahasa). Jakarta: Yayasan Obor Indonesia.

Turgut, H. (2001). 'Culture, Continuity and Change: Structural Analysis of Housing Pattern in Squatter Settlement' dalam GBER (1).

Zeizel, J. (1981). Inquiry by Design. California. 